\title{
Correction: Potential Use of SSR and ISSR Markers in Estimation of DNA Polymorphism Within Genus Vicia (vol. 52, p. 85, 2015)
}

\author{
Dragana Rajković · Ksenija Taški-Ajduković • Nevena Nagl • Milada Isakov • \\ Dragan Milić $\cdot$ Đura Karagić $\cdot$ Aleksandar Mikić
}

Summary: Due to misprint in Table 3 on page 88 , following corrections were made: in the column with primer VfG14 results for Vicia pannonica and Vicia villosa are corrected. Instead +/- sign for Vicia pannonica $(+)$ is placed, $+/(+)$ sign for Vicia villosa is replaced with + .

Table 3. Transferability of SSR primers within Vicia genus

\begin{tabular}{lcccccc}
\hline Vicia sp & VfG7 & GA4 & VfG14 & GAI1 & VfG24 & GATA5 \\
\hline Vicia faba* & $290 \mathrm{bp}$ & $230 \mathrm{bp}$ & $230 \mathrm{bp}$ & $240 \mathrm{bp}$ & - & - \\
Vicia narbonensis & + & $(+)$ & + & $(+)$ & - & + \\
Vicia ervilia & + & $(+)$ & + & $(+)$ & - & + \\
Vicia pannonica & - & - & $(+)$ & - & - & - \\
Vicia villosa & - & - & + & - & - & - \\
Vicia sativa ssp. sativa & - & - & + & $(+)$ & - & + \\
Vicia sativa ssp. nigra & + & $(+)$ & + & + & $(+)$ & + \\
Vicia grandiflora & - & - & + & $(+)$ & $(+)$ & $(+)$ \\
\hline Transferability (\%) & 50 & 50 & 100 & 75 & 25 & 62,5 \\
\hline * observed product size, + different size than in V. faba, $(+)$ same size as in V. faba, - no amplification &
\end{tabular}

Ispravka: Mogućnost primene SSR i ISSR markera u proceni

DNK polimorfizma unutar roda Vicia (vol. 52, str. 85, 2015)

Dragana Rajković $\cdot$ Ksenija Taški-Ajduković $\cdot$ Nevena Nagl $\cdot$ Milada Isakov • Dragan Milić · Đura Karagić · Aleksandar Mikić

Sažetak: Zbog omaške u obradi teksta, u Tabeli 3 na strani 88 unete su sledeće ispravke: u koloni za prajmer VfG14 rezultati za Vicia pannonica i Vicia villosa su ispravljeni. Umesto znaka $+/$ - za Vicia pannonica stavljen je znak $(+)$, a znak $+/(+)$ za Vicia villosa je zamenjen znakom + .

D. Rajković · K. Taški-Ajduković* $\cdot$ N. Nagl · M. Isakov · D. Milić ·

Đ. Karagić · A. Mikić

Institute of Field and Vegetable Crops, 30 Maksima Gorkog, 21000

Novi Sad, Serbia

e-mail: ksenija.ajdukovic@nsseme.com 
